\title{
Heritage and Development of National Culture in Music Teaching
}

\section{Han Jihong}

\author{
Linyi University, Yishui, Shandong, 276400
}

\section{Keywords: National culture; Music teaching; Inheritance; Development}

\begin{abstract}
Chinese nation has a long history and profound traditional culture. After thousands of years of inheritance and development, it forms distinctive ethnic characteristics of traditional culture. Music culture is an important part of national traditional culture. In recent years, music teaching has caused more and more attention in society. We have to inherit and develop national culture in music teaching, and attach great importance to national music teaching. This paper introduces the importance of the inheritance and development of national culture in music teaching, and proposes to inherit and develop national culture strategy in music teaching.
\end{abstract}

Every nation in the world loves its own national culture. For a nation, national culture is the spiritual pillar. National culture has a comprehensive impact on people, influencing people's thoughts and people's behavior, etc. By influencing people's way of thinking and behavior, it also seeks to promote the comprehensive development of society. Chinese nation has a long history and profound traditional culture. After thousands of years of inheritance and development, we formed distinctive ethnic characteristics of traditional culture. Traditional culture is our precious spiritual wealth of Chinese nation, which affects every Chinese child, and is an important symbol of our long history. National culture has rich content, not only including literature and art, but philosophy, religion. National music and ethics are also included in this aspect. National culture need to be inherited and developed from generation to generation. In the new era, education workers undertake an important responsibility of inheriting and developing national culture. In every subject teaching, we should attach great importance to the penetration of national culture and education. In recent years, music teaching has caused more and more attention in society. We have to inherit and develop national culture in music teaching, and attach great importance to national music teaching. Folk music is an important part of our national culture and expression form. National music is produced in the folk, which embodies national spirit and national culture with rich content, including folk opera, folk musical instruments, etc. In music teaching, we should pay attention to national music teaching, which is to inherit and develop national culture and cultivate students' sense of national pride and national spirit.

\section{THE IMPORTANCE OF NATIONAL CULTURE INHERITANCE AND DEVELOPMENT IN MUSIC TEACHING}

Music teaching is closely connected with national culture, and the two complement each other. Music culture is an important part of national culture. Music education is a form of music culture, and music culture will react on music education to make music education have more cultural connotation. With the development of the Times, music education also should keep pace with the Times. Leaving traditional music, music education will be a madrassa, and cannot have achieved a good development. At the same time, in music education, we should critically inherit traditional music culture, and promote music education's healthy development. National culture inheritance and development, and attachment of importance to national music teaching are of great significance for music teaching. The importance of music teaching inheritance and development of national culture mainly displays in several aspects.

\section{A. National music inspires students'awareness of national culture}


China has a long history, and the masses of working people created a splendid culture of our country. Working people use music to express their own feelings and desires, express feelings on life, and express their spiritual world. Working people in different historical background created excellent music culture. National music is close to the life of working people with folk wisdom, which is accepted and loved by the masses of working people, and enriches the labor people's spiritual world. National music is a representative of national culture, and has distinctive national color and full-bodied local flavor. National music embodies national spirit. In different historical period, people draw spiritual motive from national music. Excellent traditional national music has become the spiritual pillar of Chinese nation, and it is an important treasure of our national culture. Under the intense influence, Chinese nation determines to move forward. In music teaching, pay attention to national music teaching, and teachers' interpretation of ethnic music can let the students understand music cultural connotation. Let the student study ethnic music. The whole process is very good to promote national culture of our country. National music teaching process is essentially students' cognition and perception process of traditional culture. So, ethnic music inspires students' awareness of national culture. In music teaching, for example, introduce Chinese folk songs to students about creation background, artistic features, etc. of folk songs, and tell some related stories of folk songs. Folk songs in different places are distinctive and student can feel China's vast through learning folk songs, and feel the country's rich and colorful culture. National music cannot leave national musical instruments, and our country has a wide variety of ethnic musical instruments, including Suona, Urheen, Pipa, etc. Let students understand some knowledge of musical instruments, which can help students understand national culture.

\section{B. National music fosters students' national spirit}

It is well known that folk music has condensed the wisdom of people of all ethnic groups with profound cultural connotation, not only national feelings, also national spirit. All these make a rich national spirit. National music learning has a series of positive significance for students. Learning national music can cultivate students' national spirit, enhance their national consciousness, and arouse students' patriotism. In music teaching, teachers should improve teaching methods, integrate national spirit education into national music teaching, and well combine the two. Adopt some teaching methods, stimulate students' interest in national music learning, and let them perceive national spirit contained in national music. In national music teaching, the teacher first lead the students understand the connotation of the works, on the basis of understanding, grasp national feelings and spirit contained in the master works. In short, in national music teaching, combine music work closely together with the cultivation of national spirit, through specific work embody the national spirit, feel great verve and masculinity, including heroic tenacity, perseverance, etc., and feel Chinese nation's greatness. National music learning is good for students' religious faith, for students' spirits, and is helpful to inspire students' constant struggle.

\section{National music sets up students' positive outlook on life}

After the reform and opening to the outside world, our country gradually fuses into the world, and there are increasing frequent exchanges with the rest of the world. Especially the development of economic globalization, increasingly interlink of countries around the world, and with the development of science and technology, there are more convenient exchanges between countries, and culture communication gradually becomes the theme of the exchanges between countries. The fusion of different cultures collides with each other. As cultural exchanges, foreign ideas, culture, values are spread to our country and have an effect on our country's people. We can't be stuck in the past on culture, and have to learn from other cultures to promote the better development of our 
nation's culture. All is not good, and other countries' culture is not all positive. They may have dregs, bad things. At the time of learning foreign culture, some bad factors produce adverse effect on the student, confuse the students intrinsic values, so that they can't distinguish between right and wrong, have a negative attitude toward life, and lack a correct outlook on life. And national music has rich cultural connotation, communicate positive emotions, which can correct student's values, help students set up correct and positive outlook on life. Noble beautiful national music not only brings sound aesthetic feeling, and brings emotional edification, which usually contains noble sentiments and feelings. This helps the formation of students' moral quality. Affectionate national music can purify people's heart, and have the effect of incentive and sublimation on person's spirit. Appreciate national music can improve students' feel of beauty and the power to appreciate beauty, improve the ability of true respectively, and make students form the correct aesthetic view. Noble national music can play a positive role in cultivating students' noble character.

\section{THE STRATEGIES OF INHERITING AND DEVELOPING NATIONAL CULTURE IN MUSIC TEACHING}

\section{A. Perfect the course location in school music teaching}

In music teaching, curriculum is a very important link. Whether the curriculum is scientific and reasonable will directly affect the actual effect of music teaching. In the context of education reform in China, music teaching is faced with reform. At present, many problems still exist in the curriculum of music teaching in China, and more outstanding is that there is no enough emphasis on national music culture. National culture value in music teaching is ignored. In order to better implement music teaching, it is necessary to adjust the curriculum of music teaching, make the curriculum more scientific and reasonable, attach great importance to national music teaching, and let the students know more about traditional music culture. Music teaching is to improve students' music quality as the goal and to strengthen students' national consciousness as the goal. Therefore, school music teaching curriculum should be improved. At the time of optimizing curriculum, focus on letting the students understands traditional culture. In current new situation, music teaching must be combined with national culture so as to fundamentally improve the level of music teaching, and improve teaching quality of music. Music teaching reform can't just change something on the surface, and we must carry on deep reform. Around carrying forward national music culture reform, build a perfect music teaching system with inside to outside reform, so that the students could improve comprehensive music accomplishment.

\section{B. Establish a correct concept of national culture}

Inherit and develop national culture in music teaching, which is the requirement of music teaching in the new period. To achieve this goal, we must first correct music teachers' cultural concepts, correct the students' cultural concept, and make them set up correct concept of culture. The inheritance and development of national culture in music teaching is not conformism. We must correctly understand this point in music teaching. In music teaching, the need of national music in music teaching is the need of inheriting our excellent national culture. Under multicultural background, we cannot totally accept foreign culture, also we can't completely negate national culture, and we should criticize the acceptance of foreign culture, but also have critical inheriting of the excellent culture of this nation. In music teaching, teachers guide students' concept of music, let the students understand that a comprehensive understanding and studying of national music and traditional culture are of great significance to ethnic music in music learning. The teacher should lead students to appreciate ethnic music, and let students experience the unique artistic charm of traditional Chinese national music. 


\section{Develop faculty with national culture accomplishment}

In teaching activities, teachers play an important role. Teachers' quality will directly affect the teaching effect. In music teaching, in order to better inherit and develop national culture, there must be a team of high-quality teachers. Music teachers should have high quality national music culture. In school, the school should pay much attention to music teachers training, and improve their national music culture accomplishment. Through various means and methods, open music teachers' teaching view, let them set up correct concept of national music, and stand at the cultural level in music teaching. Music teachers are common with low national music culture quality. Teaching innovation is insufficient and lack macro teaching performance. The priority of music teaching is to develop high quality music teachers. Schools can organize music teachers for college education or communication, also invite ethnic music masters to make lecture to make teachers have more in-depth understanding of national music.

\section{REFERENCES}

[1] Cai Yi. Theory of Chinese national music culture inheritance [J]. Journal of Arts Education, 2008,07:62-64.

[2] Tian Renjun. Local national culture inheritance and development research in school [J]. National BBS, 2008,06: 46.

[3] Zhou Lijuan. The succession and development of national music culture in music teaching in colleges and universities [J]. Journal of Yellow River, 2015,11:167.

[4] Qin Xiao. Vocational school music teaching and national culture inheritance [J]. Journal of Music and Space, 2015, 11:167.

[5] Qi Guangyu. On vocational music tradition concept embodiment in music teaching [J]. Journal of Jiamusi Institute of Education, 2013,09:157-158.

[6] Shi Man. Theory of national culture heritage and development in primary school music education [J]. Journal of Education Teaching BBS, 2014:141-142.

[7] Zhang Tiantong. Higher normal music education and national music heritage----survey on the current situation of national music teaching in higher teachers colleges and countermeasures [J]. Chinese Musicology, 2004,01:101-115.

[8] Fan Lizhi. School music education and the inheritance of national music culture [J]. Journal of Northwest University (Philosophy and Social Sciences Edition), 2005,06: 142-145.

[9] Xu Wanmin. Theory of music education heritage of local music culture [J]. Journal of Zhangzhou Normal University (Philosophy and Social Sciences Edition), 2010, 04:105-110. 